日植病報 38: 290-298 (1972)

Ann. Phytopath. Soc. Japan 38: 290-298 (1972)

\title{
Biological Activity of Phyllostine, a Phytotoxic Compound Isolated from the Culture Filtrate of Phyllosticta sp.
}

\author{
Ryutaro SaKaI*, Rinzo Sato**, Jiro Ito*** \\ and Sadao SAKamura*** \\ 酒井隆太郎* ・佐藤倫造**・伊藤滋郎*** ・坂村貞雄 ${ }^{* * *}$ : Phyllosticta sp. の \\ 培養滤液から分離した毒物質 Phyllostine の生理活性
}

\begin{abstract}
1. Phyllostine has been isolated from the culture filtrate of Phyllosticta sp., a pathogenic fungus of red clover, as the principal toxic compound causing wilting and dark discoloration of leafy stem cuttings of red clover and it is closely related structurally to phyllosinol.

2. Phyllostine stimulated growth of red clover, lettuce and rice seedlings at a concentration range from $10^{-8}$ to $10^{-5} \mathrm{M}$. These promoting effects of phyllostine on plant growth were similar to that of phyllosinol.

3. Phyllostine at concentrations between $10^{-6}$ to $2.5 \times 10^{-4} \mathrm{M}$ promoted adventitious root formation in epicotyls of Azukia cuttings. The promoting effect of phyllostine, however, was slightly higher than phyllosinol at the same concentration level.

4. IAA-induced elongation of isolated Avena coleoptile sections was inhibited by phyllostine at a concentration range from $10^{-6}$ to $5 \times 10^{-4} \mathrm{M}$.

5. $\mathrm{GA}_{3}$-induced elongation of lettuce hypocotyls was slightly inhibited by phyllostine at a concentration range from $5 \times 10^{-5}$ to $10^{-4} \mathrm{M}$.

6. Phyllostine has antibiotic activity. The activity of phyllostine, on the whole, was about more than four times as high as that of phyllosinol.
\end{abstract}

(Received November 24, 1971)

\section{Introduction}

A new phytotoxic metabolite "phyllostine" has been isolated from Phyllosticta sp., a pathogenic fungus of red clover, as the principal toxic compound causing dark discoloration of leafy stem cuttings of red clover, and its chemical structure has been established ${ }^{5,7,8)}$ (Fig 1). Phyllostine is closely related to phyllosinol in structure, and it has similar phytotoxicity as phyllosinol. These similarities led us to study the biological effects of phyllostine on higher plants and microorganisms in comparison with phyllosinol.

\section{Materials and methods}

Preparation of phyllostine Phyllostine was isolated in a crystalline state from the culture filtrate of Phyllosticta sp. as presented in a preceding paper8) (Fig. 2). Re-crystallization from chloroform

* National Institute of Agricultural Sciences, Kita-ku, Tokyo, Japan. 農業技術研究所

** Hokkaido National Agricultural Experiment Station, Sapporo, Japan. 北海道農業試験場

*** Department of Agricultural Chemistry, Hokkaido University, Sapporo, Japan. 北海道大学農学部 


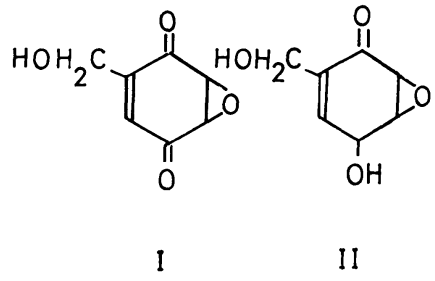

Fig. 1. Structures of phyllostine (I) and phyllosinol (II).

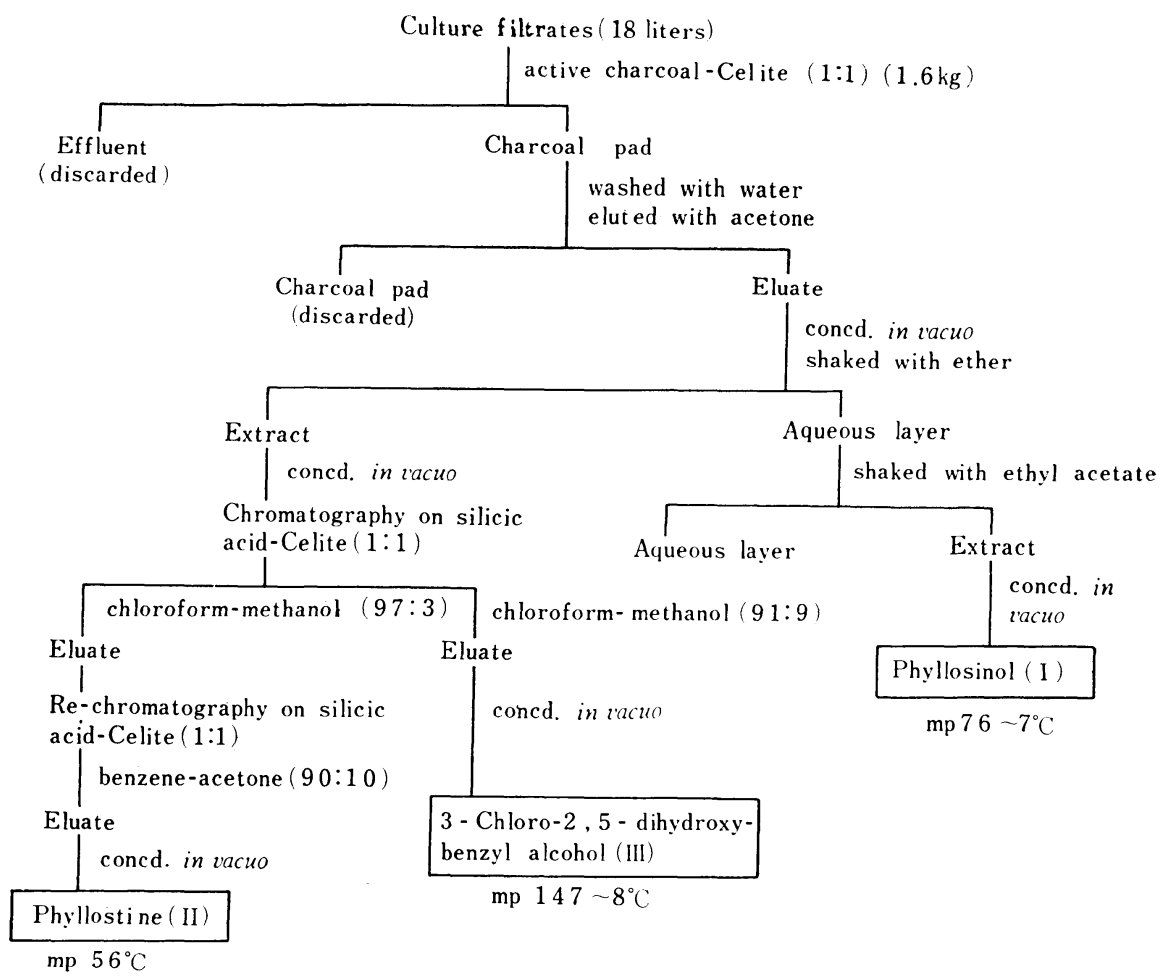

Fig. 2. Isolation procedure of the metabolites.

(I) Phyllosinol, (II) Phyllostine.

yielded pale yellow plates, $\mathrm{mp} 56^{\circ} \mathrm{C},[\alpha]_{\mathrm{D}}^{20}-105.6(\mathrm{c}=1$ in ethanol), which was assigned the molecular formula $\mathrm{C}_{7} \mathrm{H}_{6} \mathrm{O}_{4}$ by mass spectra and elementary analysis.

Seedling growth test The seedling growth test was performed according to the procedures described in a previous paper $\left.{ }^{6}\right)$.

Red clover and lettuce Seed of Trifolium pratense L. Lakeland and of Lactuca sativa, cv, Greatlake were soaked in tap water overnight and allowed to germinate at $23^{\circ} \mathrm{C}$ for $24 \mathrm{hr}$. Then, seedlings with roots of uniform size were transferred onto filter paper in a $6 \mathrm{~cm}$ Petri dishes and placed under continuous illumination in the growth cabinet at $27^{\circ} \mathrm{C}$. The Petri dish was supplied with $5 \mathrm{~m} l$ of test solution $(0.02 \mathrm{M}$ phosphate buffer, $\mathrm{pH} 5.6)$, containing phyllostine at various concentrations for the two sheets of filterpaper. The light intensity in the growth cabinet was about 4,000 lux, supplied by fluorescent tubes (combination of "Natural Day Light", Toshiba Co., and "Vitalux" for plant culture, Shinnihon-Denki Co.). 
After four days, lengths of hypocotyls and roots were measured.

Rice plant Seeds of Oryza sativa L., Norin 20 were soaked in tap water at $28^{\circ} \mathrm{C}$ for two days. Germinated seeds were selected for uniformity, and planted on cloth nets, which were set up on cylindrical bottles $5.7 \mathrm{~cm}$ in diameter and $7.5 \mathrm{~cm}$ in height. These bottles were placed in a $200 \mathrm{~m} l$ beaker filled with the test solution dissolved in $0.02 \mathrm{M}$ phosphate buffer at pH 5.6.

They were then incubated for 11 days in the growth cabinet at $27^{\circ} \mathrm{C}$.

During this period, distilled water was added to maintain the test solution at the original level. After 11 days, lengths of the shoots and roots were measured.

Azukia rooting test The rooting test was performed according to the procedures described in a previous paper6). The cutting which consisted of $5 \mathrm{~cm}$ epicotyl, a pair of primary leaves and a small bud was taken from the light-grown $\left(3000\right.$ lux at plant level, $\left.27^{\circ} \mathrm{C}\right) 10$ day old Azukia angularis "Wase-tairyu" seedling. After treating the basal parts with a test solution for $16 \mathrm{hr}$, the cuttings were transferred to distilled water and kept under about 4000 lux at $25^{\circ} \mathrm{C}$ for 7 days, and the number of roots protruded and length of rooting zone on the epicotyl were measured.

Avena straight growth test The Avena straight growth test was the same as described in the previous papers ${ }^{6}$. From the coleoptile of 3 day old etiolated seedlings of Arena sativa "Victory" $5 \mathrm{~mm}$ long sections were excised $2 \mathrm{~mm}$ below the physiological tips. Twelve of such sections were floated on a test solution and their lengths were measured after $18 \mathrm{hr}$ of dark incubation at $27^{\circ} \mathrm{C}$. The basic test medium contained $0.02 \mathrm{M}$ phosphate buffer (pH 5.3), 2\% sucrose and IAA. Phyllostine dissolved in $0.02 \mathrm{M}$ phosphate buffer ( $\mathrm{pH} 5.3$ ) was added to the basic medium.

Lettuce cotyledon test Seeds of Lactuca sativa, cv. Greatlake were sown on filter paper moistened with tap water. After $24 \mathrm{hr}$ incubation, germinated seeds of uniform shape and size were transferred to Petri dishes. Seeds were supplied with culture medium and incubated for $72 \mathrm{hr}$ in the growth cabinet (lux 3000) at $27^{\circ} \mathrm{C}$. The culture medium consisted of $\mathrm{GA}_{3}$ and phyllostine dissolved in half strength Hoagland solution.

Antibiotic activity assay Antimicrobial activity of phyllostine was studied with the agar streak dilution method using potato-glucose agar medium for fungi, and peptone-glucose agar medium for bacteria.

Phyllostine and other test chemicals in $0.02 \mathrm{M}$ phosphate buffer at $\mathrm{pH} 5.6$ and added to the medium at each concentration. The effects of sulfhydryl compounds on the antifungal action of phyllostine was determined as follows.

The required quantity (one or two molecular proportions) of the sulfhydryl compounds were dissolved in $0.02 \mathrm{M}$ phosphate buffer at $\mathrm{pH} 6.0$ and phyllostine was added to a final concentration of $2.5 \times 10^{-4} \mathrm{M}$. The mixture was kept at $27^{\circ} \mathrm{C}$ for $20 \mathrm{hr}$, and tested for antifungal activity, using the agar plate streak method.

\section{Results and discussion}

\section{Effect on growth of plant seedling}

Phyllostine promoted elongation of red clover, lettuce and rice roots at a concentration range from $10^{-8}$ to $10^{-5} \mathrm{M}$ and inhibited it at a higher concentration, $10^{-4} \mathrm{M}$ (Table 1 and 2). The growth promoting effects of phyllostine were clearly observed in roots than in shoots. These promoting effects of phyllostine on plant growth were similar to that of phyllosinol6). In the preceding paper, we suggested that phyllosinol and unsaturated lactones may behave in the same manner in root growth. The similarity between phyllostine and phyllosinol in structure leads us to speculate that 
Table 1. Effect of phyllostine on growth of plant seedlings

\begin{tabular}{cccccc}
\hline \hline \multirow{2}{*}{$\begin{array}{c}\text { Concentrations } \\
\text { of phyllostine }\end{array}$} & \multicolumn{2}{c}{ Red clover } & & \multicolumn{2}{c}{ Lettuce } \\
\cline { 2 - 3 } \cline { 5 - 6 } & Shoot & Root & & Shoot & Root \\
\hline Control & $21.2 \pm 0.45(100)$ & $23.6 \pm 1.00(100)$ & & $10.3 \pm 0.09(100)$ & $26.3 \pm 0.35(100)$ \\
$10^{-8} \mathrm{M}$ & $21.0 \pm 0.36(99)$ & $27.9 \pm 0.31(118)$ & & $11.5 \pm 0.58(111)$ & $31.7 \pm 0.47(120)$ \\
$10^{-7} \mathrm{M}$ & $22.3 \pm 0.22(105)$ & $27.1 \pm 1.34(115)$ & & $11.4 \pm 0.29(109)$ & $32.1 \pm 0.67(122)$ \\
$10^{-6} \mathrm{M}$ & $22.0 \pm 0.66(104)$ & $31.0 \pm 1.61(131)$ & & $11.3 \pm 0.68(109)$ & $35.4 \pm 0.36(134)$ \\
$10^{-5} \mathrm{M}$ & $21.1 \pm 1.02(101)$ & $29.9 \pm 0.21(126)$ & & $11.1 \pm 0.28(107)$ & $35.0 \pm 0.39(133)$ \\
$10^{-4} \mathrm{M}$ & $20.8 \pm 1.08(98)$ & $22.0 \pm 1.01(93)$ & & $10.0 \pm 1.01(97)$ & $24.7 \pm 0.72(94)$ \\
\hline
\end{tabular}

Mean length of 40 seedlings with standard error.

Parenthesized figures, $\%$ of control.

Table 2. Effects of phyllostine on growth of rice seedlings ${ }^{\mathrm{a}}$

\begin{tabular}{|c|c|c|c|c|c|}
\hline \multirow{2}{*}{$\begin{array}{l}\text { Concentrations } \\
\text { of phyllostine }\end{array}$} & \multicolumn{2}{|c|}{ Shoot } & \multicolumn{2}{|c|}{ Root } & \multirow{2}{*}{$\begin{array}{l}\text { Length of } 2 \text { nd } \\
\text { leaf sheath } \\
(\mathrm{cm})\end{array}$} \\
\hline & $\begin{array}{l}\text { Length of } \\
\text { 2nd leaf } \\
\text { (cm) }\end{array}$ & $\begin{array}{c}\text { Dry wt. } \\
(\mathrm{mg})\end{array}$ & $\begin{array}{l}\text { Length of } \\
\text { root }^{b} \\
(\mathrm{~cm})\end{array}$ & $\begin{array}{c}\text { Dry wt. } \\
(\mathrm{mg})\end{array}$ & \\
\hline Control & $12.75 \pm 0.19$ & $(7.0)$ & $5.01 \pm 0.72$ & $(3.1)$ & $3.93 \pm 0.02$ \\
\hline $10^{-8} \mathrm{M}$ & $12.71 \pm 0.26$ & $(7.7)$ & $7.25 \pm 0.60$ & (3.9) & $4.34 \pm 0.01$ \\
\hline $10^{-7} \mathrm{M}$ & $13.44 \pm 0.28$ & (8.5) & $9.92 \pm 0.24$ & $(4.1)$ & $4.44 \pm 0.01$ \\
\hline $10^{-6} \mathrm{M}$ & $13.15 \pm 0.11$ & (8.8) & $7.40 \pm 0.17$ & $(4.6)$ & $4.38 \pm 0.01$ \\
\hline $10^{-5} \mathrm{M}$ & $13.23 \pm 0.11$ & $(8.1)$ & $7.85 \pm 0.14$ & $(4.4)$ & $4.34 \pm 0.14$ \\
\hline $2.5 \times 10^{-5} \mathrm{M}$ & $12.99 \pm 0.18$ & $(7.2)$ & $5.94 \pm 0.15$ & $(3.7)$ & $3.48 \pm 0.14$ \\
\hline
\end{tabular}

a Average of 20 seedlings.

b Length of main root.

Table 3. Effects of phyllostine and phyllosinol on adventitious root formation from Azukia cuttings ${ }^{\mathrm{a}}$

\begin{tabular}{|c|c|c|c|c|c|}
\hline \multirow{2}{*}{\multicolumn{2}{|c|}{$\begin{array}{c}\text { Concentration of } \\
\text { chemicals } \\
(\mathrm{M})\end{array}$}} & \multicolumn{2}{|c|}{ Root formation } & \multicolumn{2}{|c|}{ Region of root formation } \\
\hline & & \multirow{2}{*}{$\begin{array}{c}\begin{array}{c}\text { Number of } \\
\text { roots }\end{array} \\
9.5 \pm 2.0\end{array}$} & \multirow{2}{*}{$\begin{array}{c}\begin{array}{c}\% \text { of } \\
\text { control }\end{array} \\
100\end{array}$} & \multirow{2}{*}{$\begin{array}{c}\begin{array}{c}\text { Length of } \\
\text { rooting zone } \\
(\mathrm{mm})\end{array} \\
3.8 \pm 0.32\end{array}$} & \multirow{2}{*}{$\frac{\begin{array}{c}\% \text { of } \\
\text { control }\end{array}}{100}$} \\
\hline Control & & & & & \\
\hline Phyllostine & $1 \times 106$ & $10.2 \pm 3.6$ & 107 & $5.1 \pm 1.82$ & 132 \\
\hline$"$ & $1 \times 10^{-5}$ & $10.2 \pm 3.6$ & 107 & $4.7 \pm 0.62$ & 121 \\
\hline$"$ & $1 \times 10^{4}$ & $16.5 \pm 3.5$ & 173 & $13.1 \pm 1.18$ & 337 \\
\hline$"$ & $2.5 \times 10^{-4}$ & $18.8 \pm 5.1$ & 197 & $25.3 \pm 0.61$ & 652 \\
\hline Phyllosinol & $1 \times 10 \% 4$ & $14.2 \pm 2.1$ & 147 & $16.3 \pm 1.27$ & 420 \\
\hline$"$ & $2.5 \times 10^{-4}$ & $15.2 \pm 2.3$ & 160 & $30.2 \pm 0.13$ & 778 \\
\hline
\end{tabular}

a Average of twelve seedlings. 


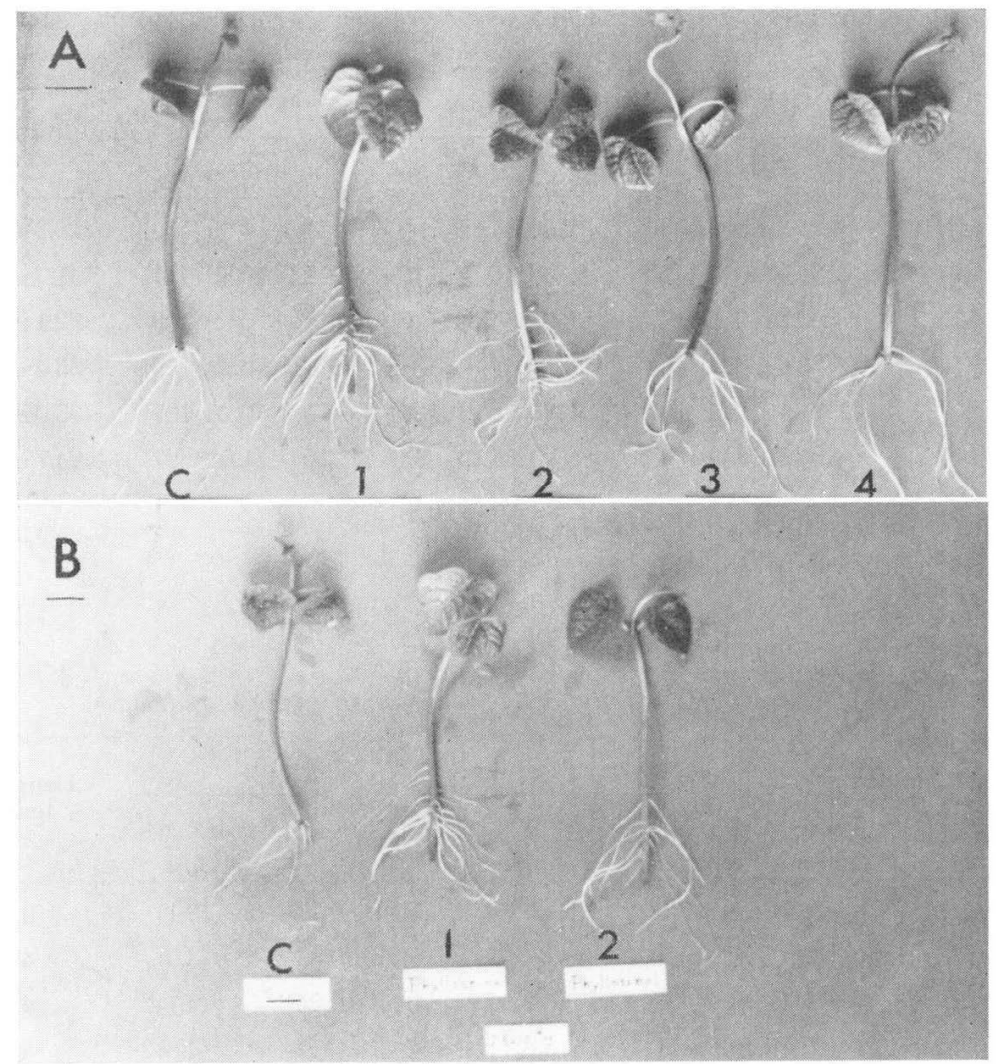

Fig. 3, A. Promotion of adventitious root formation from Azukia cuttings by phyllostine. From left, Control; $2.5 \times 10^{-4}, 1 \times 10^{-4}, 1 \times 10^{-5}$, $1 \times 10^{-6} \mathrm{M}$ of phyllostine.

B. Comparative effects of phyllostine and phyllosinol at $2.5 \times 10^{-4} \mathrm{M}$. From left, Control, phyllostine, phyllosinol.

phyllostine may behave in the similar manner as the unsaturated lacton compounds behave in plant growth $^{2,3,4)}$.

\section{Effect on adventitious root formation}

Phyllostine at a concentration range from $10^{-6}$ to $2.5 \times 10^{-4} \mathrm{M}$ promoted adventitious root formation in epicotyls of Azukia cuttings and was the most effective at $2.5 \times 10^{-4} \mathrm{M}$ (Table 3, Fig. 3, A). These results were similar to those obtained with phyllosinol. Phyllostine, however, was slightly more active than phyllosinol at the same concentration level (Fig. 3, B).

Effect on IAA-induced growth of Avena coleoptile and $G A_{3}$-induced growth of lettuce hypocotyl

Figure 4 shows that IAA-induced elongation of isolated Avena coleoptile sections was inhibited by phyllostine at a concentration range from $10^{-6}$ to $5 \times 10^{-4} \mathrm{M}$. This growth inhibition was not relieved by increasing the IAA concentrations. It indicates that phyllostine did not act as an antiauxin on the promoting effects on plant growth.

Figure 5 shows that $\mathrm{GA}_{3}$-induced elongation of lettuce hypocotyls was slightly inhibited by phyllostine at a concentration range from $5 \times 10^{-5}$ to $10^{-4} \mathrm{M}$ and the inhibition of growth was not relieved by increasing the concentration of $\mathrm{GA}_{3}$. Generally, at concentrations above $10^{-4} \mathrm{M}$ phyllostine 


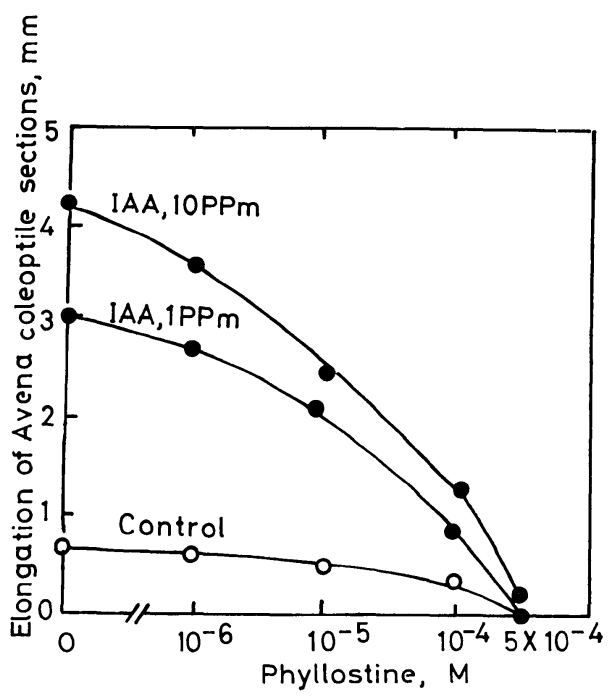

Fig. 4. Effect of phyllostine on elongation of Avena coleoptile sections induced by $1 \mathrm{ppm}$ and $10 \mathrm{ppm}$ IAA. Initial length of section, $5.0 \mathrm{~mm}$. Each point indicates an average of 12 sections.

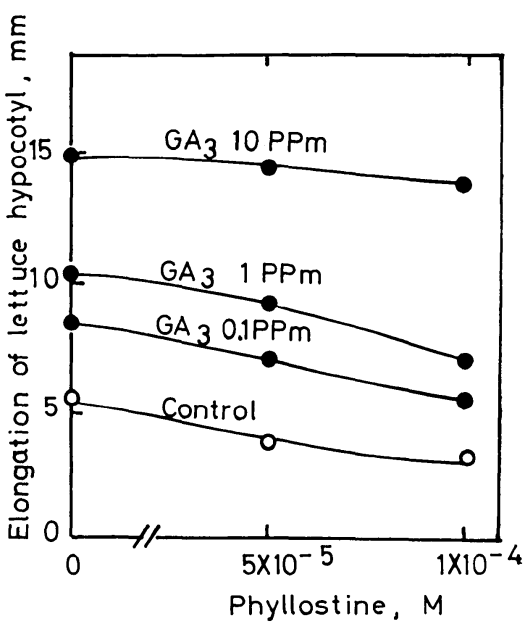

Fig. 5. Effect of phyllostine on $\mathrm{GA}_{3}$ induced elongation of lettuce hypocotyl. Each point indicates an average of 12 plants.

Table 4. Comparison of antimicrobial activity of phyllostine and phyllosinol by agar dilution method

\begin{tabular}{|c|c|c|}
\hline \multirow{2}{*}{ Test organisms } & \multicolumn{2}{|c|}{$\begin{array}{r}\text { Minimum inhibitory concentration } \\
(\mathrm{ppm})\end{array}$} \\
\hline & Phyllostine & Phyllosinol \\
\hline Colletotrichum lindemuthianum & 100 & $>100$ \\
\hline Phytophthora parasitica & 50 & $50<,<100$ \\
\hline Helminthosporium turcicum & 50 & $50<,<100$ \\
\hline Alternaria kikuchiana & 50 & $50<,<100$ \\
\hline Phytophthora capsici & 25 & $50<,<100$ \\
\hline Sclerotinia sclerotiorum & 25 & $50<,<100$ \\
\hline Pythium debaryanum & 25 & $25<,<50$ \\
\hline Cercospora beticola & 12.5 & 100 \\
\hline Helminthosporium sigmoideum & 12.5 & 100 \\
\hline Sclerotinia mali & 12.5 & 50 \\
\hline Pseudomonas ovalis & 50 & 100 \\
\hline P. tabaci & 50 & 100 \\
\hline Agrobacterium tumefaciens & 50 & 100 \\
\hline Escherichea coli & 50 & 50 \\
\hline Xanthomonas oryzae & 50 & $12.5<,<25$ \\
\hline Bacillus subtilis & 25 & 100 \\
\hline Pseudomonas coronafaciens & 25 & 50 \\
\hline P. fluorescens & 12.5 & 50 \\
\hline
\end{tabular}


Table 5. Comparison of the inhibitory effects of phyllostine and phyllosinol on growth of Phytophthora capsici, P. parasitica, Sclerotinia sclerotiorum and Alternaria kikuchiana.

\begin{tabular}{llccc}
\hline \multirow{2}{*}{ Test organisms } & Substance & \multicolumn{3}{c}{ Inhibition (\% of control) } \\
\cline { 3 - 4 } & & $12.5 \mathrm{ppm}$ & $25 \mathrm{ppm}$ & $50 \mathrm{ppm}$ \\
\hline Phytophthora capsici & Phyllostine & 46 & 66 & 90 \\
& Phyllosinol & 15 & 25 & 37 \\
P. parasitica & Phyllostine & 76 & 87 & 92 \\
& Phyllosinol & 7 & 12 & 30 \\
Sclerotinia sclerotionum & Phyllostine & 68 & 74 & 93 \\
& Phyllosinol & 0 & 12 & 46 \\
& Phyllostine & 27 & 36 & 50 \\
& Phyllosinol & 8 & 17 & 25
\end{tabular}

causes damage on tissues, while as reported in previous paper phyllosinol shows no injurious effect at the same concentration.

The inhibitory effect of phyllostine is more powerful than that of phyllosinol at the same concentration level.

\section{Antifungal and antibacterial activity}

In Table 4 and 5, antimicrobial activities of phyllostine were compared with those of phyllosinol. The activity of phyllostine, on the whole, was about more than four times as high as that of phyllosinol except those against Escherichea coli and Xanthomonas oryzae.

The effects of a sulfhydryl compounds upon the fungistatic properties of phyllostine and phyllosinol were shown in Table 6 . At $2.5 \times 10^{-4} \mathrm{M}$ phyllostine inhibited growth of Phytophthora capsici by 90 per cent.

This effects were diminished slightly by one equivalent of sulfhydryl compounds tested and two equivalent led to diminished activity by 35 to 50 per cent. Whereas, the activity of phyllosinol was diminished by one equivalent of sulfhydryl compounds by 6 to 29 per cent.

In previous paper6), we suggested that the antimicrobial activity of phyllosinol is ascribable, at least partly, to the $\alpha$, $\beta$-unsaturated ketone group. Geiger and Conn ${ }^{3)}$ reported that unsaturated ketone

Table 6. Effect of sulfhydryl compounds on antifungal activity of phyllostine against Phytophthora capsici.

\begin{tabular}{|c|c|c|c|c|c|c|}
\hline \multirow{2}{*}{\multicolumn{2}{|c|}{$\begin{array}{l}\text { Sulfhydryl compounds } \\
\text { (M) }\end{array}$}} & \multirow{3}{*}{$\begin{array}{c}\text { None } \\
52 \\
\end{array}$} & \multicolumn{4}{|c|}{ Colony diameter $(\mathrm{mm})$} \\
\hline & & & \multirow{2}{*}{$\begin{array}{c}\text { Phyllostine } \\
\left(2.5 \times 10^{-4} \mathrm{M}\right) \\
5\end{array}$} & \multirow{2}{*}{$\begin{array}{l}\text { Inhibition } \\
(\% \text { of control }) \\
90\end{array}$} & \multirow{2}{*}{$\begin{array}{c}\text { Phyllosinol } \\
\frac{\left(2.5 \times 10^{-4} \mathrm{M}\right)}{22}\end{array}$} & \multirow{2}{*}{$\begin{array}{c}\text { Inhibition } \\
(\% \text { of control }) \\
58\end{array}$} \\
\hline None & & & & & & \\
\hline Cysteine & $2.5 \times 10^{-4}$ & & 7 & 87 & 37 & 29 \\
\hline " & $5 \times 10^{-4}$ & & 27 & 48 & 36 & 30 \\
\hline Glutathion & $2.5 \times 10^{-4}$ & & 8 & 85 & 30 & 42 \\
\hline " & $5 \times 10^{\cdots 4}$ & & 26 & 50 & 39 & 35 \\
\hline Thiosulfate & $2.5 \times 10^{-4}$ & & 14 & 73 & 49 & 6 \\
\hline$"$ & $5 \times 10^{-4}$ & & 34 & 35 & 51 & 4 \\
\hline
\end{tabular}

P. capsici was grown on potato-glucose agar plate. 


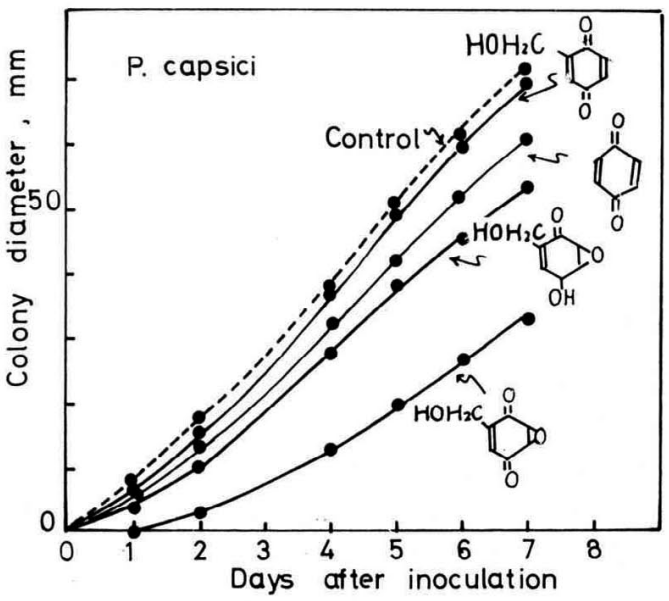

Fig. 6, A. Effects of phyllostine, phyllosinol, pquinone and 2-hydroxymethyl-1, 4-quinone on growth of Phytophthora capsici on potatoglucose agar containing $2 \times 10^{-4} \mathrm{M}$ of each chemicals.

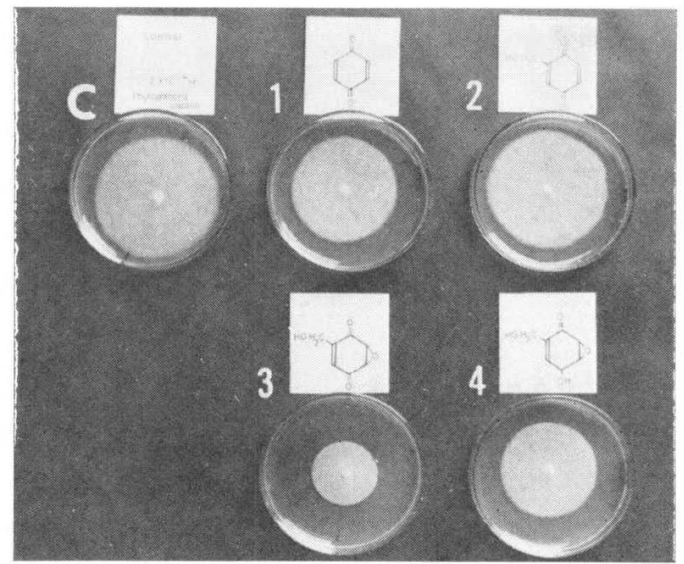

Fig. 6, B. Effects of analogs of phyllostine at $2 \times 10^{-4} \mathrm{M}$ on growth of Phytophthora capsici in potato-glucose agar.

C, Control, 1, p-quinone, 2, 2-hydroxymethyl-1, 4-quinone, 3, phyllostine, 4, phyllosinol.

reacts specifically with the sulfhydryl groups of certain enzymes. If this should be the mechanism by which phyllosinol inhibit growth of microorganisms, then one might expect that phyllostine, a substance having two carbonyl groups, would be more inhibitory against microorganisms than phyllosinol, a substance having only one carbonyl group. Subsequently, attempts were made to determine the effects of the antifungal activity of analogous compounds, phyllostine, phyllosinol, p-quinone and 2-hydroxymethyl-1, 4-quinone at a concentration of $2 \times 10^{-4} \mathrm{M}$. Fig. 6 , A and B shows that phyllosinol reduced growth considerably but was not as effective as phyllostine.

In addition, phyllostine that has an epoxy group, was more inhibitory than 2-hydroxymethyl-1, 4-quinone that has no epoxy group.

These results indicate that the antimicrobial activity of phyllostine may be attributable to the unsaturated carbonyl groups with some additional effects of the epoxide group.

\section{Literature cited}

1) Andreae, W. A. (1952). Nature, $170: 83$.

2) Burstrom, H. (1954). Physiol. Plant., $7:$ 548-559.

3) Geiger, W. B. and J. E. Coon. (1945). J. Amer. Chem. Soc., 67: 112-116.

4) Goodwin, R. H. and C. Taves (1950). Amer. J. Bot., $37: 224-231$.

5) Ichihara, A., Oda, K. and Sakamura, S. (1971). Agr. Biol. Chem., 35 : 445-446.

6) Sakai, R., Sato, R., Niki, H and Sakamura, S. (1970). Plant\& Cell Physiol., 11 : 907-920.

7) Sakamura, S., Ito, J. and Sakai, R. (1970). Agr. Biol. Chem., 34: 153.

8) Sakamura, S., Ito, J. and Sakai, R. (1971). Agr. Biol. Chem., 35: 105-110. 


\section{和文摘要}

Phyllosticta sp. 菌の培養濾液から分離した 毒物質 phyllostine の生理活性

酒井隆太郎・佐藤 倫造・伊藤滋郎・坂 村貞雄

アカクローバ罹病葉から分離したPhyllosticta sp. 菌の培養滤液から, 自然感染葉病斑類似の障害を起こす 物質として，既に報告した phyllosinol についで新物質 phyllostine を分離した。本物質は phyllosinol につい で多量に生産され，その化学構造は phyllosinol 飞類似する。本報告では phyllostine と phyllosinol の植物お よび微生物に対する生理活性を比較した。phyllostine は低濃度 $\left(10^{-8} \sim 10^{-4} \mathrm{M}\right)$ で幼植物の生充, 特に根部の生 育を促進するが高濃度 $\left(10^{-4} \mathrm{M}\right)$ で阻害する。また小豆 Cutting の下胚軸において不定根の形成を促進する。こ れらの活性は一般に phyllosinol より高い。また phyllostine は幅広い抗菌スペクトルを有し, 阻害は phyllosinol の 2 8 倍の活性を示した。また抗菌力は各種の SH-化合物により抑制が認められ，また2-hydroxymethyl-1, 4-quinone との抗菌力の比較試験等から, phyllostine の抗菌作用は, 本物質の有する $\alpha, \beta$-不飽和ケ ントおよでエポキシ基によると考えられる。 